Živojin B. Prokopović ${ }^{1}$

Tijana B. Prokopović ${ }^{2}$

Maja Lj. Arsić-Trajković ${ }^{3}$

Business school of Nis, high school - Nis
SCIENTIFIC REVIEW ARTICLE

doi:10.5937/ekonomika1603123P

Received: May 27, 2016

Accepted: July 1, 2016

\title{
TRACING OF BALANCING EXPRESSION OF RESULTS OF SUSTAINABLE DEVELOPMENT
}

\begin{abstract}
Apstract
Category sustainable development and economically consolidated subjective factor of entities are the basis of well-structured productive forces, but also the main lever of its integral development. Therefore, in all conditions of working hard for the issues of sustainable development, it is given more attention.

Solving the problems of governance of sustainable development in the entities and making optimal decisions for optimal economy, and (as part of the integrated economy) assumes the use of appropriate information subsystems. These are: operational records, statistical records and accounting records.
\end{abstract}

Key words: Sustainable development entity, information systems, records, accounting, balance...

JEL classification: M4

\section{ПРАЋЕЊЕ И БИЛАНСНО ИСКАЗИВАЊЕ РЕЗУЛТАТА ОДРЖИВОГ РАЗВОЈА}

\begin{abstract}
Апстракт
Категорија одрживи развој и економски консолидовани субјективни фактор ентитета темељ су добро структурисане производне снаге, али и основна полуга юеговог интегралног развоја. Зато се у свим условима привређивања проблематищи одрживог развоја и поклања све већа пажна.

Решавање проблематике управљања функиијом одрживог развоја у ентитетима и доношење оптималних одлука ради његове оптималне економије (као дела интегралне економије) претпоставља кориићење одговарајућих информационих подсистема. То су: оперативна евиденција, статистичка евиденција и рачуноводствена евиденција.
\end{abstract}

Кључне речи: Одрживи развој, ентитет, информаџиони системи, евиденција, рачуноводство, биланс...

\footnotetext{
${ }^{1}$ z.prokopovic@gmail.com

2 ticapro89@gmail.com

${ }^{3}$ maja1505arsic@gmail.com 


\section{Introduction}

Total economy of entities, including the economics of sustainable development, is a privilege to owners of capital on which it is, of course, and the way of solving the problem of sustainable development. The determining factor on which depends the behavior of the capital owner in this area is the level of profitability of invested capital. Without sustainable development in the future economic entities and consolidated subjective factor there is no question of a well structured productive force as the main lever of his integral development. Hence in all economic conditions the issue of sustainable development more attention is given as well as to engagement of the necessary resources for its implementation.

However, it was a mistake to think that the solution of the problems of sustainable development has only social dimension. On the contrary, everything that enters into the complex issues of sustainable development (some investment in it, caused deviations in this area, either temporarily or permanently eliminate the investors from this process) directly or indirectly affects the economy entities, and therefore the partial and total quality of its economy. Therefore, sustainable development is primarily a socio-economic category and the scientific conference hit its purpose when it decided on the basic theme "sustainable economic development".

On the other hand, such a scientific conference gets right to the specific weight precisely because it is being held in Belgrade, in the economically strongest region in Serbia, in which the entities solve the mentioned problems with the utmost interest of investors, direct capital owners and direct users of sustainable development. They, in their own name and for its own account, should identify the depth and breadth of the problem of sustainable development, to thoroughly look into all its aspects, and on the basis of it all returns and optimal business decisions affect the overall quality of business and labor

However, to be able to exercise this inviolable right to decide on this important issue, they must be on time, objectively and comprehensively informed of all the facts that influence the relative category of sustainable development and all the positive and negative repercussions associated with it. This is usual, in line with the view that the whole society and the entire organized market economy development and the realization of its development goals and may be based on a well established information system and its functional subsystems. Thus, when it comes to the management function of sustainable development entity, it should be noted that the realization of its development goals and score them can not be done without relying on adequate information system and its indicators.

It is therefore necessary to observe, in that sense, the current situation, it is objective to assess and point out all the necessary things to do to get it refined and improved in order to achieve the most favorable social results.

\section{Management of sustainable development entities function}

When it comes to managing the function of sustainable development in the entities and making optimal decisions for optimal economy (as an integral part of the 
economy), it should be noted that the solution of this problem is based on the use of several information subsystems. These are: operational records, statistical records and accounting records.

Business - task of operating records is reduced to the registration of the natural indicators (ie. quantitative) of all that relates to sustainable development, such as the type and number: specific funds, the number of engaged on issues of sustainable development and the like.

Such operational records shall be kept in individual acts of entities and serve mostly for their internal information needs, and rarely are delivered to management in general - the human resources for collation of relevant reports vault. Regardless of the lack of coordinated and documented the operational records, may nevertheless conclude that it is as certain information subsystem most widespread and that in terms of sustainable development tool (for more input and less output elements) provides competent management as relatively sufficient information to undertake necessary operative enterprise. However, it must immediately be noted that these records - given its-kind character - do not provide information on which can be viewed economics of sustainable development, much less economic repercussions arising from the formation of the costs caused by the activities of sustainable development. And that means that these operational records also can not serve as a solid and objective basis for management and decision making in all aspects of the economic function of sustainable development and its reflections on the overall economy entities.

The statistical records, as a subsystem of integral Information System entities are even less able to serve as a reliable basis for management and decision making on the functioning of sustainable development, especially for the understanding of the costs on the basis of sustainable development entities. The reason for this, as it comes down to filling prescribed statistical forms, which are sent to professional services entities, and relevant statistical institutions. These forms are more or less uniform and misfit specifics of the entity, and are often filled mechanical and routine, which has the ultimate consequence of the false vault statistical indicators that are constructed in the statistical institutions. This information is presumptive character, unrepentant very little used by management entities (ie. for their internal needs). Therefore, this information subsystem, especially when it comes to functions of sustainable development - in all its economic input and output elements - no more significance for shareholders and for the adoption of their direct decisions of vital interest to the economics and quality of business entities.

The accounting records, as a special information subsystem, is certainly the most important part of an integrated information system entities. This, above all, is because it consists of value indicators and to all those operations and transactions affecting the economic integrity of the entity, and therefore on all inbound and outbound economic determinants (investment and effects) of complete economic system. Since the function of sustainable development an integral part of the economic system rounded entities (with their input and output elements), this is it such economic category as a whole, which includes the accounting information system. The accounting records with the widest and most comprehensive database of business information in general. This stems from the recognition that accounting has the function to monitor and record all events and all operations that take place in the process of business entities and to reflect on the quality of its economy and ultimately business results. Consequently, the accounting records 
and provides all the information that express the financial investment in sustainable development, as well as all the negative repercussions arising from the adverse effects resulting from sustainable development entities. In a word, accounting records - as a specific and coherent system of values - should provide information relative abundance of particular importance for the efficient functioning of an integrated system of sustainable development and all its functional parts and effects on the effects of business entities.

However, as part of a very complex and comprehensive accounting records, of particular significance are: chart of accounts, balance sheet and income statement.

Chart of accounts ${ }^{1}$ is a method and an instrument of rational and efficient systematization account (accounts), which should allow the registration in the accounts of all relative points and parts of the process of business and labor entities. This provides a real insight into his periodic conditions, dynamics and ultimately business results as an expression of the quality of the economy. Therefore, it is better to say that the chart of accounts is a system account that synthesizes qualitative, quantitative and value indicators of the quality of the overall business process and work (and therefore of sustainable development as the complex input and output elements in this business). Accordingly, such a complex function of the chart of accounts causes its specific characteristics, which should make it a particularly important source of information for the effective performance of the functions of sustainable development, as well as the objective basis for the continuous scrutiny, evaluation and modification of the policy of sustainable development and possible revision of earlier business decisions in the area of operation of capital owners.

Chart of accounts especially enables efficient:

- control of material business (stock),

- control of the situation and trends of fixed assets and

- control of costs, expenses and income.

All of the above mentioned should provide a complex insight and control of materials and fixed assets (equipment), which requires sustainable development, as well as control costs incurred on the basis of the activities undertaken and measures for sustainable development.

However, in the present circumstances the official chart of accounts is not as systematic, especially in its analytical aspect to providing fast and accurate information on the most important elements of sustainable development and the negative repercussions for the owners of capital. Chart of Accounts does not have a special synthetic, nor analytical accounts in which to record the information on a very important element for conducting effective policy of sustainable development. Thus, the missing accounts of the impact on sustainable development, such as:

- unsustainability of the existing volume of economic,

- inequality created by the existing market structure,

- frequent changes of models of production and consumption,

- more intense competition,

- causing loss of decision with regard to sustainable development and

- withe role of businesses and the impact of other sectors on sustainable development. 
Consequently there is no value-information on all investments in this function, which is part of the whole business entities, which certainly prevented a rational policy of sustainable development by the owners of capital.

Also accounts on which are registered data on the costs incurred in connection with sustainable development are relatively poorly represented in the chart of accounts. It seems to us that the number of accounts that record expenses incurred in connection with sustainable development, is not satisfactory and does not allow the owners of capital pun and realistic insight into all costs as inputs in the process of business entities. They remain invisible and blurred many of the events that have a decisive influence on both the development of the subjective factor in the operating process, and the final output elements of this process. In a word, the existing chart of accounts available on all accounts (synthetic and analytical), which can provide complex information about the effects and all the defects of sustainable development, and therefore of all positive and negative repercussions for the final operating results of the entities and the general and common interests economy and society.

Balance sheet ${ }^{2}$ by its basic character represents the main character in the density of periodic nu global financial-material information about the entity. The balance sheet must be realistic to be: value synthetic indicator of economic processes, cycles and operations entity, a special indicator of the quality of available property (assets and their sources), as well as an indicator to quantify these qualities. Therefore it should be the basis for assessing the quality of sustainable development policy and its economy in terms of invested funds and their sources (own and others).

However, as the scheme of the balance sheet as a function of the organic integration with existing chart of accounts, it is also necessary to this balance sheet burdened same disadvantages that are typical for the chart of accounts, and as such can not be an appropriate measure to serve the owners of capital to monitor and quality assessment of sustainable development policy.

Balance of success ${ }^{3}$ is, also, an accounting document but it also according to its character is a periodic global information on business effects of business entities (ie. its total quality). He is, in fact, the specifications and analytical elaboration of synthetic stated business results in the balance sheet (ie. profit/loss). The importance of this balance is that on its jagged structure costs / expenses on the one hand, and income on the other hand, provides insight not only into a complex financial result and the overall quality of the economy entities, but also the quality of the results of its parts. Since sustainable development is an integral part of the whole business entities (in terms of output and input element) to the income statement would be that it is a solid and comprehensive information on all relevant aspects of sustainable development and the repercussions for shareholders on the overall results of operations of the entities.

However, a critical analysis of the existing chart of accounts and pointing to the incomplete coverage of all aspects of the costs caused by sustainable development entails a result of the incomplete income statement and his inability to express sub-inputs and outputs, caused by a complex of sustainable development, which zakonomerno directly and indirectly - influence the partial and total quality of business entities, and therefore the wider social results very relevant for further socio-economic development. In particular, this negative fact deprived the owners of capital in the available credible information, without which they can rationally manage and optimize decisions on the 
organization and unfolding important functions, such as the economics of sustainable development.

The previously stated clearly speaks in favor of the claim that the current system of recording and presentation of the balance of investment in the process of sustainable development and the costs caused by this activity does not meet the real needs of the market economy. In fact, no matter what the system for recording and balancing in general made significant steps forward in terms of the requirements for harmonization of the market economy, it must be noted that it is still burdened by the legacy of solid economic normativism characteristic of earlier periods of economic activity, which bore the features of poor, and therefore the total or partial disregard of the needs and demands of some immanent non-market system and its competence. And one of the essential competencies of the market system is, without doubt, the right to up to date, reliable and complete information on all phenomena and categories on which it confidently and directly discusses and decides on the merits. Such a phenomenon is also a category of complex problems of sustainable development, in particular the negative repercussions caused by activities at the owners of capital. However, we concluded that there is no chart of accounts, Balance Sheet and the Income Statement are not, as the basic instruments of accounting records and sources of accounting information system do not meet the requirements in this regard the owners of capital, because thus preventing them from realizing their right to direct the management and decision-making one of the most vital problems of their market behavior.

That unfavorable observation leads us to the belief that in this view we should urgently take appropriate measures in order to record and balance sheet presentation of all the elements relevant to the successful operation of sustainable growth brought into line with the increasing needs of capital owners.

In the first place, it means noticing the need for a broader analytical elaboration of the chart of accounts, which should provide separate analytical accounts for all aspects of sustainable development. Namely, the synthetic accounts that record business assets (in operation and construction) it is necessary to open the analytical accounts to be used to register fixed assets whose function is permanently ensuring sustainable development in the process of business entities. Also, within the accounts of origin of fixed assets is necessary to provide separate analytical accounts to incorporate these basic sources of funds, in order to obtain an accurate notion of the character of the sources for the financing of these specific funds for the work (their own and others' financing, short term, medium term, long term) .

No less important is that in the context of synthetic accounts opened for working capital and analytical accounts for certain items and materials intended function of sustainable development, as well as the analytical accounts for the registration of these sources of working capital.

Also, and perhaps more important, is the issue of broad analytical development of all types of costs, on the one hand, that arise as a result of preventive measures for sustainable development. On the other hand, it is required to have a wide analytical elaboration of bills on which the complex will be able to record all expenses and losses incurred on the basis preduzimanih measures for sustainable development. It is understood that this request concerns the retention of existing analytical accounts continued to expand them. In addition, it is necessary to further elaborate these analytical 
chart of accounts is performed in parallel with the grooming and consolidation of the existing drive operational records of resources for sustainable development.

If you approach this broad analytical elaboration of the chart of accounts, you will create preconditions for the balance sheet and income statement, as the global accounting information, become instruments of exact balance of expressing all that is relevant to improving the economics of sustainable development as an important factor in the quality of the overall economy entity

In other words, it will be possible for the total balance sheet entities to draw special subbilans sheet assets and sources relating to the function of sustainable development. This will be far more solid sub-accounting information on all aspects and factors economics of sustainable development. Also, it will be possible from the total income statement entity to draw a special item in the success that applies to all types of costs, expenses and revenues incurred on the basis of sustainable development, which directly affect the final operating results of the entity, as well as the fulfillment of its programmed development goals.

All this should enable the development of specific financial analysis (by professional service) all those issues that are of benefit to the owners of capital and their management and decision making in the complex domain of sustainable development. For the analysis of balance sheet indicators should at least establish the following:

- correlation coefficient between the costs incurred for sustainable development, on the one hand, and expenses arising from activities in this area, on the other hand,

- degree of negative repercussions of costs incurred for the sustainable development of the economy of partial quality: effectiveness, productivity and profitability

- the ratio of dependance between the total investment and sustainable development costs and losses in this area, on one hand, and the total production volume, the gross domestic product, the total revenue, profit, on the other hand, the output elements of business entities, and

- degree of conditionality reproductive ability of the entity and the accumulative costs and losses incurred by sustainable development.

\section{Conclusion}

Analysis of these relationships is, in fact, an analysis of economic sustainable development and in particular affordable form should be presented to all owners of capital to be considered on the basis of its attempt to make optimal business decisions.

This paper is written as a humble desire to draw attention to the outstanding problems of the system of recording and presentation of the balance of costs related to sustainable development. If regularity of presented observations and proposals is noticed, it remains the responsibility that a team of experts put into the task of issues and cases expand, deepen and drafting a proposal for the improvement of the mentioned system of recording and presentation of the balance of all aspects of sustainable development. 


\section{References}

IFAC-ov Etički kodeks za profesionalne računovođe, SRRS, Beograd, 2007.

Ilić, B., Stojanović, D. i Simonović, Z., (2013), Uticaj eksternih troškova na kvalitet ponude i tražnje bakra na berzanskom tržištu, Ekonomika br. 2/13, Niš, 117-128.

Kodeks profesionalne etike udruženja vlasnika profesionalnih računovdstvenih agencija, Novi Sad, 2008.

Ljubisavljević, S. i Jovanović, D., (2011), Empirical Research on Internal Audit Position of Companies in Serbia, Economic annals 192/2011. Beograd.

Ljutić, Ž.B., (2012), Uticaj napomena na kvalitet finansijskog izveštavanja, SRRS, 43. Simpozijum, Zlatibor, 2012., 220-241.

Milojević, M., (2007), Bilans stanja prema MRS, Institut za ekonomiku i finansije, Beograd.

Prokopović, B.B. i Prokopović, Ž.B., (2005), Repetitorijum o iskazivanju imovinske situacije preduzeća (2. izdanje), Proinkom, Beograd.

Prokopović, B.B., (2007), Računovodstvo (7. izdanje), Proinkom, Beograd.

Prokopović, B.B., Arsić-Trajković, M.Lj. i Pavlova, M., (2014), Međunarodni standardi i finansijsko izveštavanje korporacija u Srbiji, Ekonomika br. 1/14, Niš, 21-27.

Prokopović, B.Ž., Doktorka disertacije (20015), Međunarodni standardi finansijskog izveštavanja na bazi poštene vrednosti $i$ korporativno upravljanje u Srbiji, Fakultet za ekonomiju i inženjerski menadžment, Novi Sad.

Prokopović, B.Ž., Nikolić, M.M., Prokopović, S.K., (2015), Pristup zaštiti ekosistema i održivi razvoj, Međunarodna naučna konferencija „Životna sredina i adaptacija privrede na klimatske promene“, Beograd, 2015., knjiga apstrakata, 79.

Ranđelović, M., (2013), Strategijsko upravljanje održivim razvojem organizacije, Ekonomika br. 2/13, Niš, 174-183.

Stoilković, M., (2007), Aktuelna pitanja periodičnog finansijskog izveštavanja ocena i mogući pravci razvoja, SRRS, 38. Simpozijum, Zlatibor, 2007., 125-137.

Škobić, P., (2006), Računovodstvena regulativa u Srbiji - stanje i očekivanja, SRRS, 37. Simpozijum, Zlatibor, 2006., 275-303.

Zbirka propisa iz računovodstva, Računovodstvo i praksa br. 1/2007, Beograd, 2007.

\section{Endnotes}

1. Zbirka propisa iz računovodstva, Računovodstvo i praksa br. 1/2007, Beograd, 2007.

2. Prokopović, B.Ž., Doktorka disertacija (20015), „MSFI na bazi poštene vrednosti i korporativno upravljanje u Srbiji“, Fakultet za ekonomiju i inženjerski menadžment, Novi Sad, str. 188.

3. Ibid 